12. Джавадов Ф. М. Квалификация насильственных преступлений, совершенных с применением оружия: Автореф. дис. ... канд. юрид. наук: 12.00.08. М.: МГУ, 1985. 21 с.

13. Сердюк Л. В. Насилие: криминологическое и уголовно-правовое исследование. М.: Изд-во «Юрлитинформ», 2002. 486 с.

14. Осадчий В. І. Проблеми кримінально-правового захисту правоохоронної діяльності: дис. ... д-ра юрид. наук: 12.00.08. К.: НАВСУ, 2004. 469 с.

15. Храмцов О. М. Кримінально-правова характеристика суспільно небезпечних наслідків психічного насильства. URL: Режим доступу: http://www.nbuv.gov.ua/portal/soc_gum/Pib/ 2009_1/PB-1/pb-1_8.pdf

16. Уголовный кодекс Аргентины. URL: Режим доступу: http://constitutions.ru/archives/5847

17. Петрунев В. П. Ответственность за угрозу убийством, нанесением тяжких телесных повреждений или уничтожением имущества по советскому уголовному законодательству: Автореф. дис. ... канд. юрид. наук: 12.00.08. М.: МГУ, 1970. 21 с.

18. Правила судово-медичного визначення ступеня тяжкості тілесних ушкоджень: Наказ Міністерства охорони здоров’я України від 17 січня 1995 р. № 6. Офіційний веб-портал Верховної Ради України. URL: http://zakon4.rada.gov.ua/laws/show/z0255-95

DOI 10.31558/2518-7953.2018.1-2.11

УДК 343.53 (477)

\begin{abstract}
Л. О. Нікіменко
доцент кафедри конституційного, міжнародного і кримінального права Донецького національного університету імені Василя Стуса, канд. юрид. наук, доцент
\end{abstract}

\title{
ЩОДО ПОНЯТТЯ ТА СИСТЕМИ ЗЛОЧИНІВ У СФЕРІ ГОСПОДАРСЬКОЇ ДІЯЛЬНОСТІ
}

Ключові слова: злочин, господарська діяльність, злочини у сфері господарської діяльності, економічний злочин, господарський злочин, система злочинів, види злочинів, видовий об'єкт злочину.

Провідною сферою життєдіяльності людини є економічна сфера. Основи економічної системи, що закріплені в Конституції України, отримують свій розвиток саме в економічних правах. Основний Закон України містить незначний перелік економічних прав, серед яких важливе місце у сучасному житті займає право кожного на підприємницьку діяльність, яка не заборонена законом (ст. 42) [1]. Людина може визначитися, що вигідно для неї особисто, і заздалегідь вирішити, 
коли і що треба робити, що, від кого і в якому обсязі й на яких умовах вимагати для реалізації своїх економічних прав та інтересів, проте приватна ініціатива не може суперечити суспільній користі та моралі, завдавати шкоди особистій безпеці, правам людини та іiі гідності, порушувати норми економічної безпеки. Сьогодні особливе занепокоєння викликає зростання злочинів економічної спрямованості, що підривають не тільки економіку, але й основи конституційного ладу України. Так, за даними Міністерства внутрішніх справ України у середньому на рік викривається понад 8 тисяч злочинів у сфері господарської діяльності [2].

Економічна криза і деформований характер ринкових відносин продовжують справляти негативний вплив на стан і динаміку економічної злочинності. Завдання протидії їй відповідно до українського законодавства та наданих компетенцій виконують співробітники відповідних підрозділів Генеральної прокуратури України, Служби безпеки України, Міністерства внутрішніх справ України, Національного антикорупційного бюро України та податкової міліції Державної фіскальної служби. Вони попереджують, виявляють та проводять досудове розслідування злочинів, положення про які зібрані в окремий розділ VII чинного Кримінального кодексу України (далі - КК України) від 5 квітня 2001 р. «Злочини у сфері господарської діяльності» [3]. Ці злочини науковці називають по-різному: «економічні», «господарські», «злочини у сфері підприємництва». Усі наведені без винятку назви цієї категорії злочинів спрямовані на охорону вітчизняної економіки.

Через різні формулювання та тлумачення цього правового поняття у працівників вищезазначених органів виникають суттєві складнощі при кваліфікації різних злочинів у сфері господарської діяльності, про що свідчать показники слідчої та судової практики з цієї категорії кримінальних проваджень та аналіз юридичної літератури. Пленум Верховного Суду України у своїх постановах неодноразово давав роз'яснення спірних питань застосування правових норм про відповідальність за злочини у сфері господарської діяльності [4-6].

Питання про визначення поняття злочинів у сфері господарської діяльності та про їх класифікацію належать в юридичній літературі до числа дискусійних та $\epsilon$ чи не найбільш обговорюваними у науці кримінального права. У різні роки зазначені питання досліджувались такими вітчизняними вченими як П. П. Андрушко, Р. А. Волинець, О. О. Дудоров, В. М. Киричко, М. Й. Коржанський, В. О. Навроцький, О. І. Перепелиця, О. Е. Радужний, Є. Л. Стрельцов, В. Я. Тацій, С. Д. Шапченко, С. С. Яценко та ін. Проте у роботах цих науковців як щодо визначення, так і відносно систематизації цих злочинів немає усталеної думки. Не можна ефективно реалізовувати нормативні положення, якщо бракує теоретичної бази, на якій вони грунтуються. 
Наведене вказує на актуальність теми цього дослідження, метою якого $\epsilon$ уточнення положень щодо поняття та системи злочинів у сфері господарської діяльності.

Для досягнення поставленої мети потрібно, насамперед, розглянути підходи до вирішення зазначених питань у вітчизняній правовій доктрині. Так, П. П. Андрушко господарські злочини визначає як передбачені кримінальним законом суспільно небезпечні посягання на врегульовані державою відносини у сфері господарської (підприємницької) діяльності з виробництва суб'єктами господарювання товарів та іншої продукції, виконання робіт, надання послуг та посягання на фінансову діяльність держави. Науковець поділяє господарські злочини на шість основних груп: 1) злочини, що посягають на встановлений порядок здійснення підприємницької діяльності та окремих її видів; 2) злочини, що посягають на фінансову діяльність; 3) злочини, що посягають на встановлений порядок виготовлення і використання документів у господарській діяльності; 4) злочини, що посягають на встановлений порядок реалізації споживачам товарів і надання послуг; 5) злочини, що посягають на свободу підприємницької діяльності; 6) злочини, що посягають на відносини у сфері сільськогосподарського виробництва [7, с. 24]. Свого часу у власній монографії, присвяченій кримінально-правовій характеристиці злочинів у сфері господарської діяльності, О. О. Дудоров справедливо звернув увагу на те, що запропонована П. П. Андрушком дефініція господарських злочинів включає в себе окрему вказівку на посягання на фінансову діяльність держави, при цьому об'єкт господарських злочинів обмежується відносинами з приводу виробництва і реалізації товарів, виконання робіт, надання послуг, та відносини, пов'язані з фінансовою діяльністю держави, в ньому не виокремлюються [8, с. 29].

На думку В. О. Навроцького, господарські злочини - це передбачені нормами КК України суспільно небезпечні посягання, які заподіюють істотну шкоду системі господарювання. Господарські злочини науковець поділяє на три групи: 1) посягання на інтереси споживачів; 2) перешкоджання правомірній підприємницькій діяльності; 3) порушення порядку заняття господарською діяльністю (злочинне ставлення до матеріальних ресурсів; фінансові зловживання; порушення заборон та обмежень у сфері господарства). Однак, сам вчений обумовлює, що далеко не всі ці господарські злочини посягають на ринкову систему господарювання - щонайменше це стосується ухилення від сплати податків, деяких інших посягань [9, с. 22].

Коржанський М. Й. господарськими називав злочини, які посягають на суспільні відносини, що утворюють систему господарювання і визначають порядок виробництва, розподілу і використання матеріальних цінностей, благ і природних ресурсів. Проведення систематизації господарських злочинів науковець 
вважав недоцільним, через що за основу аналізу брав порядок їх закріплення у КК України [10, с. 315].

Як умисне діяння у сфері господарської діяльності, що заподіює шкоду суспільним відносинам, які складаються з приводу виробництва, розподілу, обміну i споживання товарів, робіт, послуг, визначають злочини у сфері господарської діяльності В. М. Киричко, О. І. Перепелиця і В. Я. Тацій. Правознавці виділяють таку систему цих злочинів: 1) у сфері кредитно-фінансової, банківської і бюджетної систем; 2) у сфері підприємництва, конкурентних відносин та іншої діяльності господарюючих суб'єктів; 3) у сфері банкрутства; 4) у сфері використання фінансових ресурсів та обігу цінних паперів; 5) у сфері обслуговування споживачів; 6) у сфері приватизації державного та комунального майна [11, с. 403-405]. Наведена класифікація є надмірно розгалуженою та доволі суперечливою.

Необгрунтовано розширеною вбачається система злочинів у сфері господарської діяльності, яку пропонують С. Д. Шапченко і С. С. Яценко: 1) злочини, що посягають на встановлений порядок здійснення господарської діяльності та окремих її видів; 2) злочини, що посягають на фінансову діяльність; 3) злочини, що посягають на встановлений порядок виготовлення і використання документів в господарській діяльності; 4) злочини, що посягають на встановлений порядок формування та витрачання бюджетних коштів; 5) злочини, що посягають на встановлений порядок реалізації споживачам товарів і надання послуг; 6) злочини, що посягають на свободу господарської діяльності; 7) злочини, що посягають на відносини у сфері приватизації державного чи комунального майна [12, с. 208].

Згідно з класифікацією злочинів у сфері господарської діяльності, що запропонована О. О. Дудоровим, існують злочини: 1) проти порядку обігу грошей, цінних паперів, інших документів; 2) проти системи оподаткування; 3) проти системи бюджетного регулювання; 4) проти системи валютного регулювання; 5) проти порядку переміщення предметів через митний кордон; 6) проти порядку зайняття підприємницькою та іншою господарською діяльністю; 7) проти прав і законних інтересів кредиторів; 8) проти добросовісної конкуренції; 9) проти прав і законних інтересів споживачів; 10) проти порядку приватизації. У той же час сам автор класифікації вказує на їі умовність [8, с. 63]. Вбачається, що й така система має надмірно розгалужену структуру.

Волинець Р. А. систему злочинів у сфері господарської діяльності, з урахуванням останніх змін кримінального законодавства, бачить також роздрібнено: 1) злочини проти системи грошового обігу та порядку обігу деяких документів; 2) злочини проти фондового ринку; 3) злочини проти системи оподаткування i системи загальнообов'язкового державного соціального страхування; 4) злочини проти бюджетної системи; 5) злочини проти порядку переміщення предметів через митний кордон України; 6) злочини проти порядку зайняття господарською 
діяльністю; 7) злочини проти прав кредиторів; 8) злочини проти засад добросовісної конкуренції та встановленого порядку охорони та використання засобів індивідуалізації учасників господарського обороту, товарів і послуг; 9) злочини проти порядку приватизації [13, с. 188].

Інакше виглядає побудова системи економічних злочинів, запропонована О. Е. Радужним: 1) злочини в сфері підприємницької діяльності; 2) злочини, пов'язані з виявом монополізму і недобросовісної конкуренції); 3) злочини в сфері фінансових інтересів держави та інших учасників господарської діяльності; 4) злочини в сфері торгівлі і обслуговування населення; 5) злочини в сфері приватизації [14, с. 94]. Однак і вона викликає деякі зауваження, основне з яких полягає у доцільності об'єднання в одну групу злочинів першої, другої та четвертої груп.

Є. Л. Стрельцов розуміє господарський злочин як вчинення приватною або посадовою особою при здійсненні господарської діяльності умисного або необережного суспільного небезпечного діяння, що завдає істотної шкоди цій корисній діяльності. Оригінальним є й запропонований цим науковцем поділ господарських злочинів на групи: 1) злочини у сфері підприємництва; 2) злочини у сфері послуг; 3) злочини у фінансово-кредитній сфері; 4) злочини у сфері сільського господарства [15, с. 207]. Однак, як і в раніше наведених класифікаціях, не враховується та обставина, що будь-яка діяльність прибуткового характеру у сфері матеріального чи нематеріального виробництва $є$ підприємництвом, отже розмежовувати злочини у сфері підприємництва та злочини у сфері послуг, сільського господарства чи якоїсь іншої комерційної діяльності помилково.

Зважаючи на запропоновані класифікації господарських злочинів, специфіку видового об'єкту цих злочинів, що взятий за основу в усіх існуючих класифікаціях, злочини у сфері господарської діяльності можна поділити на:

1) злочини проти фінансових інтересів держави та інших учасників господарської діяльності: виготовлення, зберігання, придбання, перевезення, пересилання, ввезення в Україну з метою використання при продажу товарів, збуту або збут підроблених грошей, державних цінних паперів, білетів державної лотереї, марок акцизного податку чи голографічних захисних елементів (ст. 199 КК); незаконні дії $з$ документами на переказ, платіжними картками та іншими засобами доступу до банківських рахунків, електронними грошима, обладнанням для їх виготовлення (ст. 200 КК); незаконне виготовлення, зберігання, збут або транспортування з метою збуту підакцизних товарів (ст. 204 КК); нецільове використання бюджетних коштів, здійснення видатків бюджету чи надання кредитів 3 бюджету без встановлених бюджетних призначень або з їх перевищенням (ст. 210 КК); видання нормативно-правових актів, що зменшують надходження бюджету або збільшують витрати бюджету всупереч закону (ст. 211 КК); ухилення від сплати податків, зборів (обов'язкових платежів) (ст. 212 КК); ухилення від сплати єди- 
ного внеску на загальнообов'язкове державне соціальне страхування та страхових внесків на загальнообов'язкове державне пенсійне страхування (ст. 212-1 КК); незаконне виготовлення, підроблення, використання або збут незаконно виготовлених, одержаних чи підроблених контрольних марок (ст. 216 КК); доведення банку до неплатоспроможності (ст. 218-1 КК); доведення до банкрутства (ст. 219 КК); порушення порядку ведення бази даних про вкладників або порядку формування звітності (ст. 220-1 КК); фальсифікація фінансових документів та звітності фінансової організації, приховування неплатоспроможності фінансової установи або підстав для відкликання (анулювання) ліцензії фінансової установи (ст. 220-2 КК); шахрайство 3 фінансовими ресурсами (ст. 222 КК); маніпулювання на фондовому ринку (ст. 222-1 КК); підроблення документів, які подаються для реєстрації випуску цінних паперів (ст. 223-1 КК); порушення порядку ведення реєстру власників іменних цінних паперів (ст. 223-2 КК); виготовлення, збут та використання підроблених недержавних цінних паперів (ст. 224 КК);

2) злочини проти порядку зайняття підприємницькою та іншою господарською діяльністю: контрабанда (ст. 201 КК); незаконний обіг дисків для лазерних систем зчитування, матриць, обладнання та сировини для їх виробництва (ст. 203-1 КК); зайняття гральним бізнесом (ст. 203-2 КК); фіктивне підприємництво (ст. 205 КК); підроблення документів, які подаються для проведення державної реєстрації юридичної особи та фізичних осіб-підприємців (ст. 205-1); протидія законній господарській діяльності (ст. 206 КК); протиправне заволодіння майном підприємства, установи, організації (ст. 206-2 КК); легалізація (відмивання) доходів, одержаних злочинним шляхом (ст. 209 КК); умисне порушення вимог законодавства про запобігання та протидію легалізації (відмиванню) доходів, одержаних злочинним шляхом, або фінансування тероризму (ст. 209-1 КК); порушення порядку здійснення операцій з металобрухтом (ст. 213 КК); незаконне використання знака для товарів і послуг, фірмового найменування, кваліфікованого зазначення походження товару (ст. 229 КК); незаконне збирання з метою використання або використання відомостей, що становлять комерційну або банківську таємницю (ст. 231 КК); розголошення комерційної або банківської таємниці (ст. 232 КК); незаконне використання інсайдерської інформації (ст. 232-1 КК); приховування інформації про діяльність емітента (ст. 232-2 КК);

3) злочини проти прав споживачів: умисне введення в обіг на ринку України (випуск на ринок України) небезпечної продукції (ст. 227 КК);

4) злочини проти порядку приватизації: незаконна приватизація державного, комунального майна (ст. 233 КК).

Підсумовуючи вищенаведене, під злочинами у сфері господарської діяльності можна розуміти умисні суспільно небезпечні діяння (дї або бездіяльність), передбачені нормами розділу VII Особливої частини КК Украӥни, щзо посягають 
на фінансові інтереси держави та інших учасників господарської діяльності, порядок зайняття підприємницькою та іншою господарською діяльністю, права споживачів, порядок приватизачії. Систему злочинів у сфері господарської діяльності дочільно представити таким чином: 1) злочини проти фінансових інтересів держави та інших учасників господарської діяльності; 2) злочини проти порядку зайняття підприємницькою та іншою господарською діяльністю; 3) злочини проти прав спожсивачів; 4) злочини проти порядку приватизачії.

Врахування запропонованих положень може сприяти однозначному тлумаченню досліджуваних у статті питань працівниками відповідних державних органів задля правильної кваліфікації злочинів у сфері господарської діяльності при здійсненні ними своїх службових повноважень.

1. Конституція України: Прийнята на п'ятій сесії Верховної Ради України 28 червня 1996 р. Відомості Верховної Ради України. 1996. № 30. Ст. 141. (Із змінами).

2. Про криміногенну обстановку в Україні. Офіційний веб-портал МВС Украӥни. URL: http://mvs.gov.ua/ua/news/

3. Кримінальний кодекс України: Закон України від 5 квітня 2001 р. Відомості Верховної Ради Украӥни. 2001. № 25. Ст. 131. (Із змінами).

4. Про практику застосування судами законодавства про відповідальність за окремі злочини у сфері господарської діяльності: Постанова Пленуму Верховного Суду України від 25 квітня 2003 р. № 3. Офіиійний веб-портал Верховної Ради Украӥни. URL: http://zakon3.rada. gov.ua/laws/show/va003700-03/card2\#Card

5. Про практику застосування судами законодавства про кримінальну відповідальність за легалізацію (відмивання) доходів, одержаних злочинним шляхом: Постанова Пленуму Верховного Суду України від 15 квітня 2005 р. № 5. Офіиійний веб-портал Верховної Ради України. URL: http://zakon3.rada.gov.ua/laws/show/v0005700-05

6. Про судову практику у справах про контрабанду та порушення митних правил: Постанова Пленуму Верховного Суду України від 3 червня 2005 р. № 8. Офіиійний веб-портал Верховної Ради Украӥни. URL: http://zakon3.rada.gov.ua/laws/show/v0008700-05

7. Андрушко П. Злочини у сфері господарської діяльності за чинним Кримінальним кодексом: проблеми систематизації, криміналізації та декриміналізації. Підприємництво, господарство і право. 1998. № 12. С. 18-25.

8. Дудоров О. О. Злочини у сфері господарської діяльності: кримінально-правова характеристика: Монографія. К.: Юридична практика, 2003. 924 с.

9. Навроцький В. О. Господарські злочини. Лекції. Львів: Юрид. фак-т Львівського державного ун-ту ім. Івана Франка, 1997. 60 с.

10. Коржанський М. Й. Кримінальне право України. Частина Особлива. К.: Генеза, 1998. $658 \mathrm{c}$.

11. Кримінальне право України: Особлива частина: підручник / За ред. В. В. Сташиса, В. Я. Тація. 4-те вид., переробл. і допов. Х.: Право, 2010. 608 с.

12. Кримінальне право України: Практикум: Навч. посібник / Кер. авт. кол. Яценко С. С. К.: Юрінком Інтер, 2010. 325 с. 
13. Волинець Р. Система злочинів у сфері господарської діяльності з урахуванням останніх змін кримінального законодавства. Підпиємництво, господарство і право. 2017. № 11. C. $184-189$.

14. Радужний О. Е. Кримінальна відповідальність за незаконне збирання, використання та розголошення відомостей, що становлять комерційну або банківську таємницю: монографія. Х.: Ксилон, 2008. 202 с.

15. Стрельцов Е. Л. Экономическая преступность в Украине: курс лекций. Одесса: АО БАХВА, 1997. 572 c. 